\title{
Determinants of moral attitudes toward stem cells
}

\author{
Agnieszka Żok ${ }^{1, B-E}$, Jadwiga Wiertlewska-Bielarz ${ }^{2, C-E}$, Ewa Baumn ${ }^{1,2, A-F}$ \\ ${ }^{1}$ Division of Philosophy of Medicine and Bioethics, Poznan University of Medical Sciences, Poland \\ 2 Department of Social Sciences and Humanities, Poznan University of Medical Sciences, Poland \\ A - research concept and design; $B$ - collection and/or assembly of data; $C$ - data analysis and interpretation; \\ $D$ - writing the article; $E$ - critical revision of the article; $F$ - final approval of the article
}

\section{Address for correspondence \\ Agnieszka Żok}

E-mail:agzok@ump.edu.pl

\section{Funding sources}

None declared

\section{Conflict of interest}

None declared

Received on June 10, 2020

Reviewed on July 2, 2020

Accepted on September 20, 2020

\begin{abstract}
Background. The paper presents an analysis of opinions concerning the use of stem cells (SCs), using tools developed in the field of moral psychology.

Objectives. To determine the factors that affect beliefs regarding the status of SCs and to evaluate the impact of these factors. The paper investigated whether factors of a moral nature prevail over the knowledge that makes it possible to use SCs in practice.
\end{abstract}

Material and methods. The analysis of psychological perception is based on a study carried out on a group of 172 Polish and 161 English-speaking first-year medical students. The study was conducted between 2005 and 2007, and in 2019 at the Poznan University of Medical Sciences (Poland).

Results. Knowledge is not the main factor that differentiates approaches towards the use of SCS. The importance of religion in the lives of the respondents has a significant impact on the perception of the use of SCS, and is associated with indications of ethically saturated terms. Focusing on the usefulness of cells is associated with lesser significance of religion and greater value placed on scientific knowledge.

Conclusions. Although the research results indicate a correlation between religiousness and the respondents' perception of the use of SCS, further research is needed into the relationship between the influence of scientific knowledge on views related to SCs.

Key words: stem cells, bioethics, moral psychology, medical ethics, education

\section{Cite as}

Żok A, Wiertlewska-Bielarz J, Baum E. Determinants of moral attitudes toward stem cells. Adv Clin Exp Med. 2020;29(12):1379-1387. doi:10.17219/acem/127678

DOI

10.17219/acem/127678

\section{Copyright}

Copyright by Author(s)

This is an article distributed under the terms of the

Creative Commons Attribution 3.0 Unported (CC BY 3.0)

(https://creativecommons.org/licenses/by/3.0/) 


\section{Introduction}

A significant problem that concerns contemporary researchers, doctors, medical students, ethicists, and philosophers is not whether we are technically capable of performing a complicated procedure, but whether we should perform it or whether we have a moral right to do so. ${ }^{1}$ The disciplines that cause fundamental dilemmas and ethical controversies in modern biology and medicine are transplantology, regenerative medicine, genetic engineering and, in particular, the use of embryonic stem cells (ESCs) in modern therapy. ${ }^{2}$ Ethical issues became a widely discussed topic in November 2018 when He Jiankui of the Southern University of Science and Technology in Shenzhen, China, announced the birth of twin girls, Lulu and Nana, after he had edited the DNA in their embryos. ${ }^{3}$ Another example of ethically controversial research is to create animal embryos that contain human cells and transplant these into surrogate animals. This type of research was approved in 2019 in Japan. ${ }^{4}$ Still in need of improvement, genome editing therapy raises more ethical than technical controversies. An example is mitochondrial transfer (pronuclear transfer (PNT) and maternal spindle transfer (MST)), which despite its proven therapeutic effectiveness, is not approved in the EU (except for the UK) or the USA.

Stem cells (SCs) were defined in the 1940s and 1950s during studies on the effects of ionizing radiation on animals. They are characterized by their self-renewing potential and ability to reproduce and differentiate. ${ }^{5}$ Stem cells, based on their potential, are classified as totipotent, pluripotent, multipotent, and single-potent. The first ones are SCs that are present at the earliest stages of ontogenesis and can transform into all forms of embryo and placenta tissue. Stem cells can also be classified into 4 groups corresponding to their different origins: ESCs, fetal SCs, adult SCs, and induced pluripotent SCs. ${ }^{6}$ Research on the therapeutic use of SCs is constantly developing. Scientists are experimenting with ways to selectively target the blood-making cells within the body for destruction. Early studies suggest that the approach could make blood SCs transplants - powerful but dangerous procedures that are used mainly to treat blood cancers - safer and thereby broaden their use. The studies come as evidence piles up that such transplants can also treat some autoimmune disorders and genetic diseases. ${ }^{7}$ The possibilities of the therapeutic use of SCs are constantly increasing.

In 2019, according to a PubMed database search using the keywords "stem cells" and "human", 7295 scientific articles were published concerning applications of SC therapy in human beings. An attempt has also been made to use pluripotent SCs with the clustered regularly interspaced short palindromic repeats (CRISPR) technique. ${ }^{8}$ Due to the ethical controversies that are still aroused by the use of SCs, despite their long-term therapeutic use, we have made an attempt to analyze students' attitudes towards this subject. In view of the ethical and social dilemmas involved, collecting, culturing and experimenting on embryonic and fetus SCs is legally restricted in many countries. ${ }^{6}$ Moreover, some experiments with ESCs have led to the formation of cancerous cells and teratomas. Work on the implementation of a safe ESC line is still in progress. ${ }^{9}$

The question of what really determines human moral judgment, and worldviews is becoming fundamental to the further development of biomedicine. ${ }^{10}$ Hence, a study was conducted at the University of Medical Sciences in Poznan (Poland) on a group of 172 Polish and 161 English-speaking first-year medical students in 2007 and again in 2019. The main objective of the study was to analyze the claim that the potential development and future success of SC therapy is determined not only by the progress of biological sciences but also by legal regulations and social approval of the issue in question. The problem lies in the fact that we cannot rely only on the technological capabilities of medicine, but also on our acceptance or rejection of controversial medical techniques. Ethical aspects must not be overlooked when making fundamental decisions, and at the same time, it can be assumed that attitudes towards the issues strongly correlate with the level of relevant knowledge. ${ }^{11}$

Therefore, the specific objective of the study was to determine the attitudes of medical students towards transplantation techniques using SCs, taking into account the influence of factors such as the level of the respondents' medical knowledge, their religious affiliation and the role it plays in their lives. Also included is an analysis of changes in the respondents' knowledge and views over the course of 12 years. One particularly interesting factor is the influence of the students' knowledge and their attitude towards religion on the terms they used to talk about SCs. This influence was analyzed from the perspective of moral psychology.

\section{Material and methods}

The study was based on questionnaire surveys conducted between 2005 and 2007, and again in 2019, involving 333 students of medical departments. The students were divided into 4 groups constituting statistical subgroups according to the year and language of their study curriculum (Table 1).

Table 1. The number of respondents

\begin{tabular}{|l|c|c|c|}
\multicolumn{1}{c}{$\begin{array}{c}\text { Department } \\
\text { of Medicine }\end{array}$} & $\begin{array}{c}\text { Year } \\
\text { of study }\end{array}$ & $\begin{array}{c}\text { Survey } \\
\text { year }\end{array}$ & $\begin{array}{c}\text { Number } \\
\text { of respondents }\end{array}$ \\
\hline Polish & 1 & 2007 & 100 \\
\hline English & 1 & 2007 & 100 \\
\hline Polish & 1 & 2019 & 72 \\
\hline English & 1 & 2019 & 61 \\
\hline
\end{tabular}


The questionnaire used to analyze the students' beliefs concerning the ethical dimensions of using SCs was based on the following questions:

1. Please indicate the sources of your knowledge concerning stem cells.

2. Do you know any sources of obtaining stem cells?

3. Which of the phrases listed below do you associate with embryonic stem cells?

4. Would you like to be involved in research on stem cells after graduating?

All the questions asked in the survey were open-ended, which made it possible to respond beyond the options provided. The students filled out the questionnaire independently and anonymously, and a section concerning their demographic and social affiliations was placed at the end of the form.

Subgroups were created on the basis of the answers to particular questions, and were compared as an important element of the research process. The results of the survey were analyzed using R v. 3.5.1 statistical software (R Foundation for Statistical Computing, Vienna, Austria; http:// www.R-project.org/). The statistical significance of differences between the compared groups was determined using the Fisher-Freeman-Halton test. P-values under 0.05 were considered statistically significant. The results obtained were visualized as donut and alluvial diagrams generated using ggplot 2 and RColorBrewer software (both from R Foundation for Statistical Computing). ${ }^{12}$

A constant common feature of all the respondents was studying at the Department of Medicine of the Poznan University of Medical Sciences. Religion, attitude toward religion, and toward specific issues in ethics and bioethics were treated as features; non-researchable variables included nationality, age, gender, and origin. ${ }^{13}$ A special focus was put on the changes in the features outlined above over a period of 12 years, which spanned a turbulent time in the development of the medical sciences, when many ethically questionable therapies were becoming standard. Stem cell therapy was chosen as an example.

\section{Results}

Our analysis of the findings included a comparison of the data from the questionnaires. The first step was to perform an analysis based on techniques characteristic of sociological research. The data obtained was also compared to trends observed in society. Following this, the analysis was carried out from the perspective of moral psychology.

As a source of knowledge about SCs, Polish and English-speaking students starting their medical education between 2005 and 2007 used university resources, for example lectures and seminars, university textbooks or other academic literature, as well as other sources of knowledge (the Internet, radio and television, press articles).
Both Polish and English-speaking students starting their education in 2019 were much more likely to gain knowledge about SCs from university textbooks and academic lectures. This may suggest that curricula and academic textbooks have been updated to include SC therapy. A difference was noted between the questionnaires from 2007 and 2019 in declarations concerning Internet-based knowledge. This is undoubtedly linked to the increase in web accessibility and the growing importance of popular science publications, where breakthroughs are often described even before they appear in peer-reviewed scientific journals, and which are easy to access via the Internet.

Over the course of the study, there was an increase in declared knowledge SC harvesting sources among both Polish and English-speaking students. However, it is interesting to note that the declared increase in knowledge among Polish students was much higher than among English-speaking students. The increase was just below the threshold of statistical significance. However, it should be stressed that as early as 2005 and 2007, Englishspeaking students declared much more knowledge than their Polish peers. This could be related to the fact that in the USA, for example, the use of ESCs in therapy began in 1998, ${ }^{14}$ whereas in Poland, the use of significantly less controversial cord blood cells in treatment did not start until 2000..$^{15}$

Language is an important tool for reflecting and shaping moral judgments. In many instances, the language constructions used by the respondents reflected their worldviews and attitudes to the issues in question.

The students' responses to what they associated with the term ESCs indicate a significant difference between the responses obtained between 2005 and 2007 and in 2019. Today students are much more likely to consider SCs genetic material than those who started their studies 12 years ago. In 2019, definitely fewer students described SCs as human beings or potential human beings than in the 2005-2007 questionnaires. This may corroborate an increase in the students' scientific knowledge and a smaller share of philosophical values in moral decision-making.

The analysis of the responses provided by Polish and English-speaking students showed statistically significant differences in the students' attitudes in 2005-2007 and in 2019. In both time periods, English-speaking students were more willing to take up work related to SCs than their Polish peers. In both cases, however, the interest in conducting such research after graduating was higher (Fig. 1).

The answers provided by Polish and English-speaking medical students showed a clear tendency towards secularization: In the latest survey, students attached much less significance to religion in life than 12 years earlier. The secularization of students' views seems to correlate with the aforementioned increase in their interest in using SCs in therapy. 
A

Please indicate the source that you obtain your knowledge concerning stem cells from? 2007 Program in Polish 2019 Program in Polish
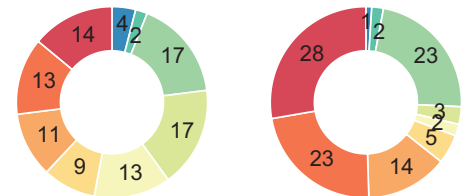

2007 Program in English 2019 Program in English
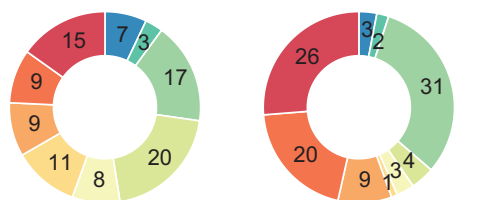

Uninars

University books

Scientific literature

Medical press

Scientific inserts in regular press

Radio and television

The Internet

Discussions with experts

Other sources
C

Which of the phrases listed below do you associate with embryonic stem cells? 2007 Program in Polish 2019 Program in Polish
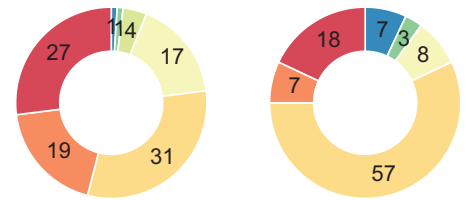

2007 Program in English 2019 Program in English
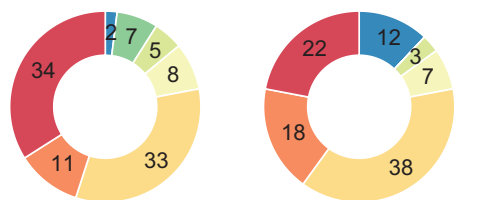

tial human being An embryo with human dignity Genetic material A human being

A legal and sensitive member of society

Surplus genetic material

Other
Religious background

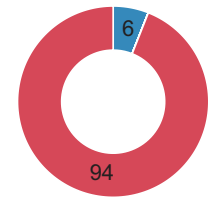

2007 Program in Englist 2019 Program in Englis
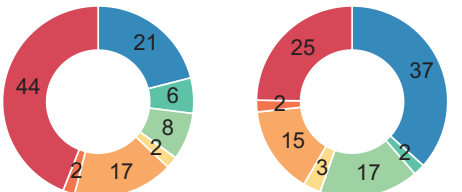

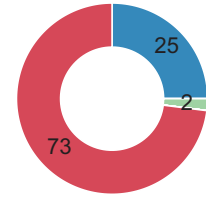

Roman Catholic Orthodox Christian Protestant Christian Muslim Jewish

Buddhist

Hindi

Other/atheist

\section{$B$}

Do you known any sources of obtaining stem cells?

2007 Program in Polish 2019 Program in Polish
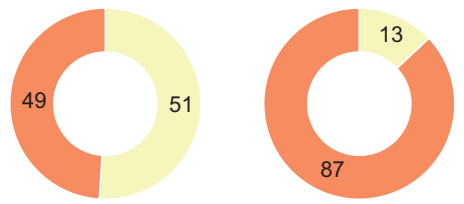

2007 Program in English 2019 Program in English Yes
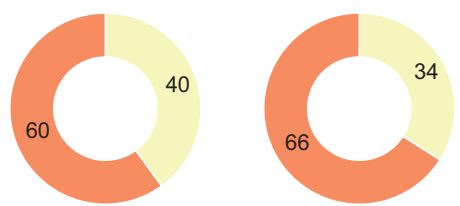

Would you like to be involved in research on stem cells after graduating? 2007 Program in Polish 2019 Program in Polish
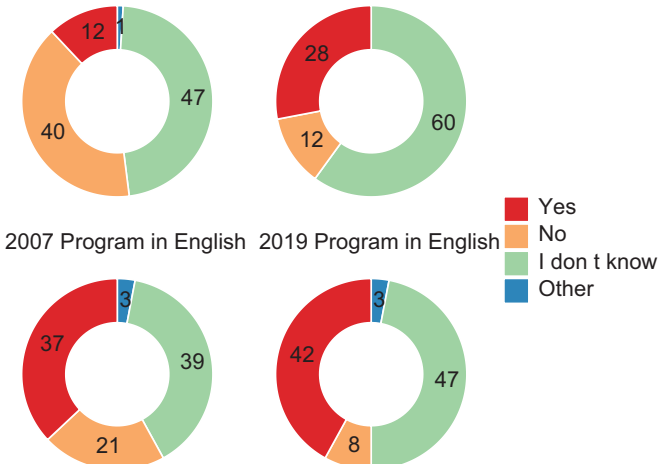

Other

F How significant is religion in your life?

2007 Program in Polish 2019 Program in Polish
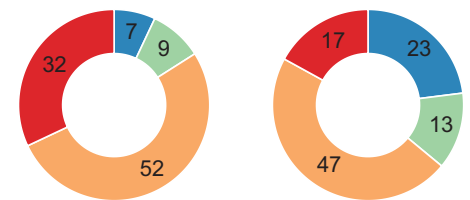

2007 Program in English 2019 Program in English

Very significant
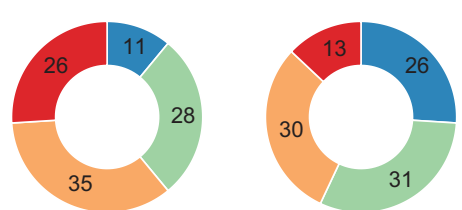

Fairly significant

Not very significant

Not significant at all

Fig. 1. Donation graphs showing the percentage distributions of the responses to the questions presented above the charts

A. Please indicate the sources of your knowledge concerning stem cells. B. Do you know any sources used to obtain stem cells? C. Which of the phrases listed below do you associate with embryonic stem cells? D. Would you like to be involved in research on stem cells after graduating? E-G. Religion and the significance of religion in life

\section{Discussion}

The results presented above form the basis of an interesting comparative study of changes that have taken place in the respondent groups. The findings can be elaborated on and analyzed from various points of view. One of the most intriguing aspects seems to be the shift in perception of the SCs status. Our analysis will argue that the perception of SCs was of a moral nature. The main aim of the analysis is to show what plays an important role in forming beliefs concerning the status of SCs. Therefore, it seems appropriate to use tools developed in the field of moral psychology.

Moral psychology is a field that seeks to understand the specificity of morality as a property that modifies human behavioral-mental activity in relation to the presence 
of another human. In particular, it seeks to explain why certain behaviors are absolutely acceptable or absolutely unacceptable, and why certain motives or objectives do not need to be justified while others are debatable. The doctrine of moral psychology must meet certain criteria. ${ }^{16}$ The aim of the psychology of morality is to analyze and explain in the most reliable manner possible the moral judgment that prevails in a given environment and the norms that prevail within it. Moral psychology tries to find the motives that push people toward behavior that is praised or punished in a given environment. The study of the theory in moral psychology has demonstrated that the current challenge for theory development and research in morality is to consider the complex and multifaceted nature of the psychological antecedents and implications of moral behavior connecting different mechanisms. ${ }^{17}$

\section{Analysis of the findings concerning changes in how stem cells are perceived}

To determine the status of SCs, a number of terms were used in the study, which differ mainly in the degree of moral/ethical saturation. Below they are presented from the most morally saturated to the most professional:

- a legal and sensitive member of society;

- a human being;

- a potential human being;

- an embryo with human dignity;

- genetic material;

- surplus genetic material;

- other.

Moral saturation means that these terms:

1) are frequently used in discussions of ethical concepts that reflect on morality;

2) have connotations associated with moral assessments;

3) are associated with perceptions of humans as having special properties, about which Ingarden wrote: "Man... is the only being who feels humiliated by his evil deeds and tries to atone for his guilt". 18,19

The term 'genetic material' indicates that there are certain useful properties of SCs, while 'surplus' indicates a lack of such properties. The term 'other' is interpreted as indecision as to one's attitude toward SCs, suggesting doubt as to what characteristics should be assigned to them. This is important, as shown by Wojciszke's research ${ }^{20}$ indicating that features belonging to the moral domain have a decisive influence on shaping the observer's impression/perception. For example, it shows that:

- Moral judgment is more saturated with affect than competence;

- In the moral (M) domain, negative information is more decisive and diagnostic than positive information, whereas in the competence $(C)$ domain, the opposite is true. The effect of this asymmetry is that the integration of incongruent information results in a negative bias in the $\mathrm{M}$ domain and a positive bias in the $\mathrm{C}$ domain. ${ }^{20}$ It seems quite reasonable to treat the terms used in the questionnaire as belonging to the $\mathrm{M}$ domain and the $\mathrm{C}$ domain. In the case of SCs, it is difficult to talk about personality, but by assigning a given status to $\mathrm{SCs}$, the students clearly assigned to them specific features of a moral or competence-related nature.

Therefore, it can be concluded that over the course of 12 years, the status of SCs has changed in such a way that fewer and fewer people perceive them within a moral classification: Polish students from $67 \%$ in 2007 to $33 \%$ in 2019, and English-speaking students from 58\% to 50\%, respectively. With regard to designations indicating that SCs have a usable nature, the share of Polish students rose from 32\% to 60\%, and the share of English-speaking students slightly fell from $40 \%$ do $38 \%$. In the case of the latter, there was a significant rise of $10 \%$ in responses indicating hesitancy or doubt (other) in comparison to $+5 \%$ among Polish students. This means that the changes in the perception of SCs cannot be explained by a simple shift in beliefs. Whereas in Polish students it is possible to say that this is the case, in Englishspeaking students it is not. Consequently, it is necessary to look at correlations with other factors.

It is interesting that the shift in perceptions of SCs is accompanied by 3 other changes: in the respondents' sources of information about SCs, in their ideas about the potency of SCs and in their declarations concerning the importance of religion in their lives. In the case of Polish students, the share of respondents for whom religion is not significant rose by $16 \%$, and this is almost the same as the decline in respondents for whom religion is very significant, namely by $15 \%$. With regard to English-speaking students, the increase was $15 \%$, whereas the decrease was $13 \%$. This comprises nearly complete symmetry. Moreover, these are extreme positions on the scale, referring to strong declarations. The "grey zone" concerning religious declarations is comparable in all the study situations, ranging between $63 \%$ and $60 \%$. Thus, the secularization of both Polish and English-speaking students over the 12 years was comparable, so it would not account for significant differences in perceptions of SCs in those 2 groups.

Regarding the increase in knowledge, the most considerable shift of $38 \%$ is observed among Polish students, whereas among the English-speaking respondents, this is merely $6 \%$. Thus, the increase in knowledge could explain why SCs are seen from a more useful perspective than before. This may undermine Wojciszke's thesis that moral beliefs are of significant importance to perception.

\section{Knowledge and emotion-related indicators}

In the study, the students were not asked about their feelings towards or knowledge on SCs, albeit one can assume that the predictors of these are the students' declarations concerning the significance of religion in their lives and their sources of knowledge on SCs. Religion was opposed to knowledge, and the fundamental difference between 
them seemed to be in the irrational elements, including the presence of emotional elements.

As shown by research on the human brain, there are some coded universal evolutionary mechanisms that provide for generating moral judgments. According to Hauser, Baron-Cohen and Churchland, ${ }^{21-23}$ areas of the brain responsible for both rational thinking and experiencing feelings are activated in order to generate moral judgments. However, there is an ongoing debate on which is more important to the formation of moral judgments: the ability to think rationally or to experience emotions. The advocates of the first school of thought include Kant, the utilitarian philosophers, and Bloom, ${ }^{24,25}$ a contemporary moral psychologist. They do not eliminate emotions as a source of moral beliefs but are rather of the opinion that positively valenced behaviors require the involvement of rational thinking. Their opponents, whose precursor was Hume, include Haidt ${ }^{26}$ and Damazio. ${ }^{27}$ In particular, Haidt links emotions to religious beliefs. Another intriguing concept that seeks to explain humans' ability to generate opinions about the world is the so-called "left-brain interpreter" proposed by Gazzaniga, whereby humans have both the ability and the need to create a coherent (though not necessarily rational) explanation of the phenomena in the world. ${ }^{28}$ Religion is a system of beliefs that explains these phenomena in a coherent but not a rational way. ${ }^{16,29}$ Moral psychology offers a strong argument for treating religious beliefs as a predictor of the existence of emotions. Christianity in particular perceives SCs within personal categories, namely, those to which we can attribute characteristics of competence (knowledge, free will) and emotions (for example, love, care and compassion).

An indicator that predicts knowledge of the competencerelated features of SCs is the ability to identify the sources of this knowledge. This ability does not necessarily prove the possession of such knowledge. Still, if one considers which sources the respondents identify, the assertion that students in 2019 had greater academic and scientific knowledge than in 2007 seems justified. There was a considerable increase in academic and scientific expertise among Polish students - 23\% - whereas among Englishspeaking students the increase was $12 \%$. The popularity of academic sources grew when the students did not use the Internet. However, at the starting point, the Englishspeaking students' knowledge was higher $(+11 \%)$ than Polish students. Hence it is possible to see this as a specific balancing of these levels. The 2019 respondents did not look for information in popular sources, whose share in obtaining information fell by about $20 \%$. In general, it is possible to assume that current students have greater knowledge, and that it is of better quality. Figures 2, 3 depict this situation in detail.

Considering the selected indicators as predictors of emotions and knowledge, one can say that when assigning a status to SCs, the respondents did so with a considerably less emotionally charged attitude than 12 years ago. ${ }^{30}$ It should be noted that in the case of Polish students, this was related to a 'useful/objective' approach towards SCs. It would seem that this approach was brought about by an increase in high-quality knowledge, and by a decline in the proportion of respondents who declared involvement in religion. Despite this decline, the number of Polish students who declared religious involvement was still nearly twice as high as the number of English-speaking students. This indicates that emotions pertaining to faith/religion play a more significant role than knowledge in their attitude toward the use of SCs. The fact that the respondents were believers did not prevent them from simultaneously acknowledging the usefulness of SCs. What is more, 23\% of Polish students declared that religion had no significance in their lives,

Please indicate the source that you obtain your knowledge concerning stem cells from, 2019 Program in Polish

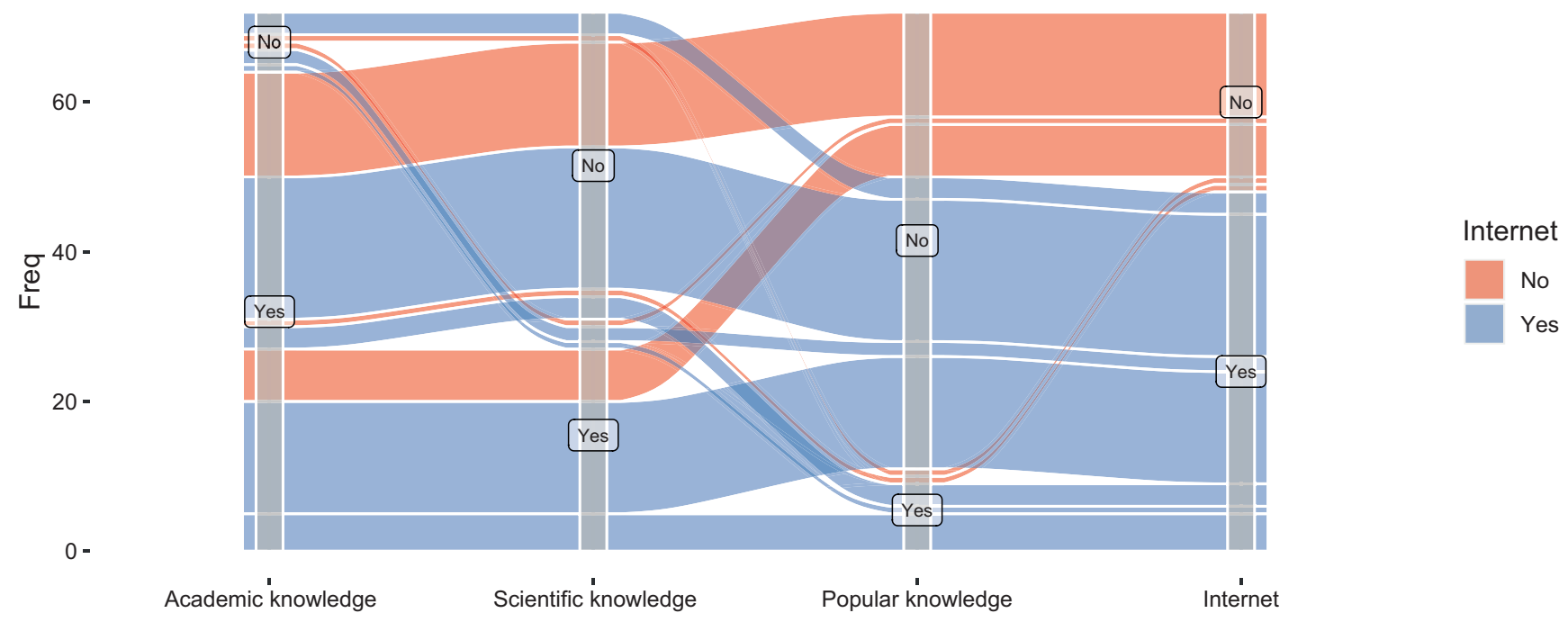

Fig. 2. Comparison of knowledge declared by Polish students with information obtained from the Internet 
Please indicate the source that you obtain your knowledge concerning stem cells from, 2019 Program in English

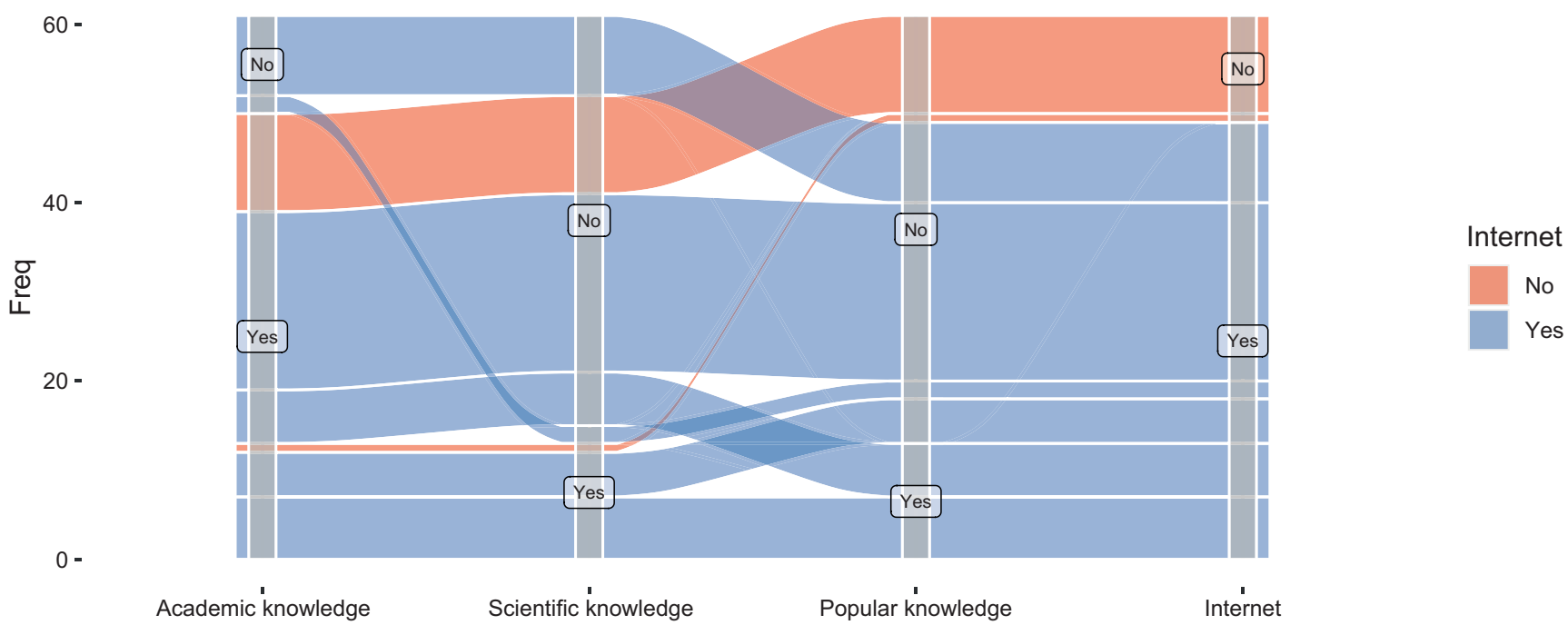

Fig. 3. Comparison of knowledge declared by English-speaking students with information obtained from the Internet

\section{Program in Polish}

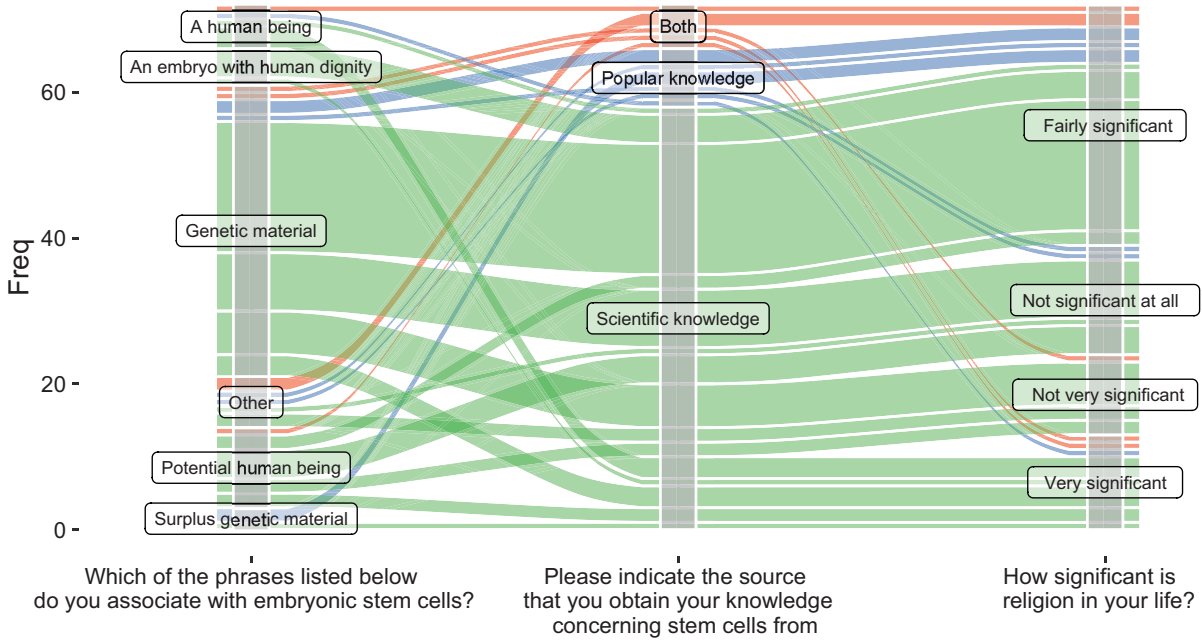

Please indicate the source that you obtain your knowledge concerning stem cells from

Both

Popular knowledge

Scientific knowledge

Fig. 4. Comparison of knowledge declared by Polish students with the significance of religion in their lives

which according to our theory would mean they determined the status of SCs based on knowledge only. This means that they should have viewed this issue strictly from the perspective of useful or non-useful features, but many of these students see SCs as potential human beings. This would mean that knowledge is a modifier rather than a major factor that impacts on their perception of SCs, which would correspond to the findings of Wojciszke.

As far as the English-speaking students were concerned, the share of respondents who declared that religion was of no significance in their lives was $26 \%$, i.e., slightly above the percentage of Polish students stating that. Despite this, it is possible to observe an even wider variety of attitudes towards the status of SCs than among Polish students. The current English-speaking students were less eager to attach moral features to SCs than 12 years ago, but at the same time, they did not see them from a utilitarian point of view; they expressed doubts about their status.

Finally, it is worth noting that the increase in knowledge declared by the students in 2019 was not paralleled by an increase in their interest in using SCs in therapy in the future.

Figures 4, 5 show the relationships between the respondents' knowledge, religion and perceptions of the SCs status.

\section{Conclusions}

As demonstrated above, knowledge is not the main factor that differentiates approaches towards SCs. Polish students with scientific knowledge defined SCs in various 


\section{Program in English}

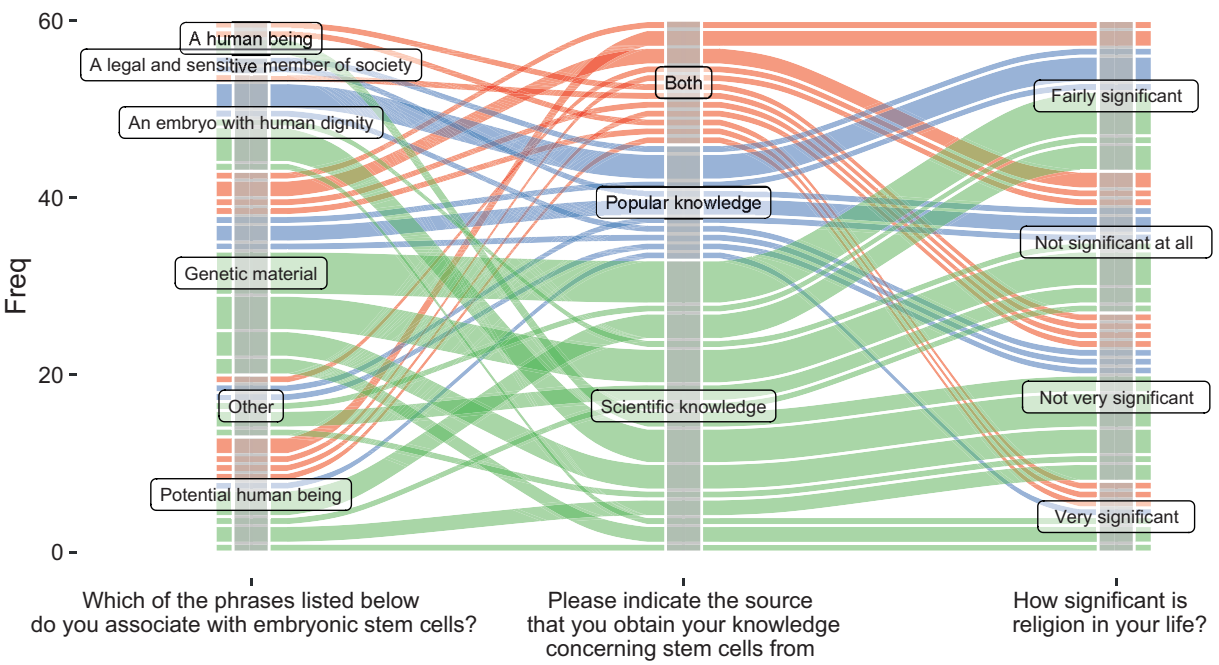

Please indicate the source that you obtain your knowledge concerning stem cells from Both

Popular knowledge

Scientific knowledge

Fig. 5. Comparison of knowledge declared by English-speaking students with the significance of religion in their lives

ways. What differentiates their definitions is the significance of religion in their lives. In the case of students who declared that religion was (very) important to them, terms that were ethically saturated definitely outweighed the other terms, with the exception being 'legal and sensitive member of society', which is an extreme term that nobody chose. When religion was unimportant in student's life, less ethically saturated terms like 'genetic material', 'other' and to a lesser extent 'potential human being' were used. Knowledge may modify attitudes in the case of respondents who indicated the term 'surplus genetic material'. These respondents declared that their knowledge was derived from popular sources, and, at the same time, that religion was fairly important to them. In this situation, it is religion that determines the non-usefulness of SCs. In the case of respondents who did not have a definite attitude towards religion, terms indicating the usefulness of SCs prevailed over other terms.

In the case of the English-speaking students, one can observe a greater polarization of terms concerning the status of SCs: $50 \%$ of the terms were morally saturated, $38 \%$ were utilitarian and $12 \%$ were unspecified. In general, the proportions were similar to those among the Polish students. Nonetheless, contrary to their Polish peers, the Englishspeaking students did not select terms expressing a nonuseful nature (e.g., 'surplus'), but, interestingly, $3 \%$ of them selected an extremely ethically saturated term (i.e., 'a legal and sensible member of society'). This $3 \%$ consisted of respondents who used non-scientific knowledge and, intriguingly, those for whom religion either did not matter at all or was quite meaningful. It may be possible to hypothesize that the significance of religion connects with the selection of ethically saturated terms, while usefulness saturation is connected with attaching less meaning to faith.
Although the results of this research indicate something about the respondents' religiousness, their sources of information and their perceptions of SCs, this study is only preliminary. The influence of scientific knowledge on students' views needs to be further analyzed, since it should be the basis of decisions made by scientists and workers in healthcare systems.

\section{ORCID iDs}

Agnieszka Żok (D) https://orcid.org/0000-0002-5560-5432

Jadwiga Wiertlewska-Bielarz (1) https://orcid.org/0000-0003-3655-2790 Ewa Baum (D) https://orcid.org/0000-0002-0503-0562

\section{References}

1. Centre for Public Opinion Research. Survey No. 3383: Values and norms in the lives of Poles [Wartości i normy w życiu Polaków]. Warszawa, Poland: CBOS; 2005.

2. Centre for Public Opinion Research. Survey No. BS/100/2007: Opinions on organ transplantation [Opinie o przeszczepianiu narządów]. Warszawa, Poland: CBOS; 2007.

3. Sample I. Gene mutation meant to protect from HIV 'raises risk of early death', The Guardian. June 3, 2019. https://www.theguardian. com/science/2019/jun/03/gene-mutation-protect-hiv-raises-riskearly-death. Accessed June 15, 2019.

4. Cyranoski D. Japan approves first human-animal embryo experiments. https://www.theguardian.com/science/2019/jun/03/genemutation-protect-hiv-raises-risk-early-death. Accessed June 15, 2019.

5. Olszewska-Słonina DM, Styczyński J, Drewa TA, Czajkowsk R. Komórki niezróżnicowane - źródła i plastyczność. Adv Clin Exp Med. 2006; 15(3):497-503.

6. Koźlik M, Wójcicki P. The use of stem cells in plastic and reconstructive surgery. Adv Clin Exp Med. 2014;23(6):1011-1017.

7. Ledford $\mathrm{H}$. Targeted stem cell attack could make transplanted safer. Nature. 2019;576(7785):18-19.

8. Hazelbaker DZ, Beccard A, Angelini G, et al. A multiplexed gRNA piggyBac transposon system facilitates efficient induction of CRISPRi and CRISPRa in human pluripotent stem cells. Sci Rep. 2020;10(1):635. doi:10.1038/s41598-020-57500

9. Ye J, Bates N, Soteriou D, et al. High quality clinical grade human embryonic stem cell lines derived from fresh discarded embryos. Stem Cell Res Ther. 2017;8(1):128. doi:10.1186/s13287-017-0561-y 
10. Singer P, ed. A Companion to Ethics. Oxford, UK: Blackwell Publishing; 2016.

11. Meith D. Going to the roots of the stem cell debate. The ethical problems of using embryos for research. EMBO Rep. 2000;1(1):4-6.

12. Wickham H. ggplot2: Elegant Graphics for Data Analysis. New York, USA: Springer; 2016.

13. Babbie E. The Practise of Social Research. Boston, MA: Wadsworth Publishing; 2012.

14. Thomson JA, Itskovitz EJ, Shapiro SS, et al. Embryonic stem cell lines derived from human blastocysts. Science. 1998;282(5391):1145-1147.

15. Styczyński J. Przeszczepianie krwi pępowinowej. Forum Pediatr Prakt. 2018;13(2):49-55.

16. Haidt J, Kesebir S. Morality. In: Fiske S, Gilbert D, Lindzey G, eds. Handbook of Social Psychology. Hoboken, NJ:Wiley Blackwell; 2010:797-832.

17. Ellemers N, Toorn van der J, Paunov Y, Leeuwen van T. The psychology of morality: A review and analysis of empirical studies published from 1940 through 2017. Pers Soc Psychol Rev. 2019;23(4):332-366. doi:10.1177/1088868318811759

18. Ingarden R. Książeczka o człowieku. Kraków, Poland: Wydawnictwo Literackie; 2003.

19. Andersen Nawrot AM. The Utopian Human Right to Science and Culture. London, UK: Routledge; 2016.

20. Wojciszke B, Bazińska R, Jaworski M. On dominance of moral categories in impression formation. Pers and Soc Psychol Bull. 1998;24(12): 1251-1263.
21. Hauser M. The liver and the moral organ. Soc Cogn Affect Neurosci. 2006;1(3):214-220. doi:10.1093/scan/nsl026

22. Churchland PS. A neurophilosophical slant on consciousness research. Prog Brain Res. 2005;149:285-293.

23. Churchland PS. The significance of neuroscience for philosophy. Funct Neurol. 2008;23(4):175-178.

24. Bloom P. Against Empathy: The Case for Rational Compassion. New York, USA: Ecco; 2016.

25. Bloom P. Just Babies: The Origins of Good and Evil. New York, USA: The Crown Publishing Group; 2013.

26. Haidt J. The emotional dog and its rational tail: A social intuitionist approach to moral judgment. Psychol Rev. 2001;108(4):814-834.

27. Damasio A. The Strange Order of Things: Life, Feeling, and the Making of Cultures. New York, USA: Pantheon; 2018.

28. Gazzaniga M. Who's in Charge? Free Will and the Science of the Brain. New York, USA: Ecco/HarperCollins; 2012.

29. Damasio H, Grabowski T, Frank R, Galaburda AM, Damasio AR. The return of Phineas Gage: Clues about the brain from the skull ofa famous patient. Science. 1994;264(5162):1102-1105. doi:10.1126/ science. 8178168

30. Baum E, Musielak M. Approach of Polish medical students to ethical problems related to transplantation. Arch PerinatMed. 2008;14(3):51-53. 